\title{
Understanding the Nature of Accounts Using Comprehensive Tools to Understand Financial Statements
}

\author{
Alessio Faccia \\ $\mathrm{PhD}$, Dr., Lecturer, Coventry University, UK \\ Dominick Mosco \\ Washington, New Jersey, USA
}

\begin{abstract}
Accounting is an integral part of the financial and economic activity of economic entities, regardless of the type of activity and industry in which the enterprise operates. This paper summarizes the arguments and counterarguments in the scientific discussion regarding the nature of accounts in accounting practice. The purpose of the study is to deepen the analysis of European financial accounting practices, in particular in the context of the use of methodological support for the classification of the nature of accounts. Particular emphasis is placed on the evolution of accounting practices: an analysis of the major evolutionary stages that have occurred in different historical periods in accordance with the social needs of society and the economic and financial consequences of such transformational changes. The systematization of literary sources on the subject made it possible to identify three key stages of the evolutionary development of accounting and the essential nature of accounts, in particular: 1) the prerequisites for the emergence of financial and accounting, confirmed by a written accounting record dated 1494;2) implementation of business continuity accounting based on the use of adjusting records and in-depth study of the nature and nature of accounts; 3) substantiation of the practical implementation of the triple record based on the implementation of blockchain technology. Based on the theoretical studies, the author substantiates the need to use in accounting practice a three-dimensional method of accounting by economic entities, which will more accurately reflect the financial transactions carried out by the company and avoid possible economic mistakes. The study postulates the need to integrate the third book within the accounting system. Summarizing, the author substantiates the need to develop in the future convergent methods of balancing the dual accounting system and maintaining accounts with the third book.
\end{abstract}

Keywords: financial and economic activity, financial reporting, accounting, double-entry, evolutionary development.

JEL Classification: A200, M400, M410, N800.

Cite as: Faccia, A., Mosco, D. (2019). Understanding the Nature of Accounts Using Comprehensive Tools to Understand Financial Statements. Financial Markets, Institutions and Risks, 3(3), 19-28. http://doi.org/10.21272/fmir.3(3). 18-27.2019.

(C) The Authors, 2019. This article is published with open access at Sumy State University.

\section{Introduction}

This research aims to assess the basics of accounting, through the nature of accounts and the analysis of the development of accounting practices. The historical socio-economic context has influenced and was influenced by the development of accounting practices.

Since the double-entry bookkeeping system was introduced by Luca Pacioli (Pacioli, L., 1494; Houghton Budd, C., 2016), anyone approaching accounting always struggled to understand why an amount should be recorded in the debit side or the credit side for each T-Account (the informal term that identifies the appearance of the bookkeeping entries, according to the shape they assumed when they were designed manually) in the ledger. Most people resign themselves to memorize, mechanically, where (debit or credit) to record the amounts of each transaction, simply by habit. 
The use of the words debits and credit to identify, respectively, the left and right section of the double entry, is linked to the naming of the sections according to the origin of the system. However, the use of the words debits and credit, which currently no longer have any intrinsic meaning, are now even misleading. It would probably be more effective to call the two sections of each accounts, left section and right section, so as to avoid any confusion. In fact, for example, the increase of a payable (that is a debt) is recorded in credit (right-hand section) and vice versa the increase of a receivable (that is a credit) is recorded in debit (lefthand section).

Although almost all of the international widespread accounting dedicated literature (Sullivan, M.C., Benke Jr., R.L., 1997; Needles, B.E., Powers, M., 2012; Spiceland, D., 2016; Libby, R., 2017; Wild, J., 2017; Weygandt, J.J., Kieso, D.E., Kimmel, P.D., 2017; Warren, C., Reeve, J.M., Duchac, J., 2018; Williams, J., 2018 ) is based on the explanation and the study of the accounting equation, however the analysis of the nature of the accounts represents a prerequisite that cannot be ignored. Undoubtedly, the accounting equation is useful to explain different dynamics of accounting and it is especially useful to prepare the financial statement (especially the balance sheet and the income statement) at the end of the period (O’Bryan, D., Berry, K.T., Troutman, C., Quirin, J.J., 2000). The research, however, has revealed that the nature of accounts has many controversial classifications. Although in many modern international books there is no classification, in the few in which it does appear it is based on the original one suggested by Luca Pacioli at the end of the sixteenth century. However, advanced and refined studies were carried out by the Italian Doctrine on the analysis of the nature of the accounts. In general, the accounts are analyzed under various aspects and the nature of accounts currently bases the studies of the accounting of each Italian university, but it is unfortunately almost still unknown abroad. The translation and dissemination of these analyzes will undoubtedly offer a more complete view of the accounting process, not only based on the study of the accounting equation, which represents its synthesis and not its origin.

It is essential to understand the reasons that led to the origin of the double entry and the consequences generated by its introduction. At the end of the fifteenth century commercial exchanges in the Mediterranean were very intense, particularly among the Italian maritime republics (including Venice) and Muslim traders in the Middle East. It is also likely that the double-entry bookkeeping system described in the book by Luca Pacioli originated from the possible influence of the practice of Muslim accounting, practiced and implemented by the Venetians (Zaid, O.A., 2000).

The development of industrial companies (starting from the industrial revolution, in the eighteenth century, which allowed for mass production), whose duration was no longer limited to the achievement of a single business project, brought to necessity to distribute dividends at least annually. At that time, the need to implement adjusting entries also arose. That need, in turn, led us to study the nature of the accounts, according to (1) the accrual basis of accounting, recording revenues on the income statement only when they are earned; and (2) the matching principle of accounting, reporting expenses on the income statement in the period in which the related revenues are earned.

Despite the auditing and controls, commercial frauds have unfortunately always occurred. The bad accounting practices that lead to an incorrect representation of the financial statements, nevertheless, have become more widespread. Nowadays, since accounting practices are crucial for the financial globalization, it is essential to find a way to curb this challenge.

The advanced studies (Yuji I., 1986) on the triple entry (Simoyama, F.D.O., Grigg, I., Bueno, R. L. P., \& Oliveira, L.C.D., 2017) have further highlighted how double-entry bookkeeping cannot be considered as an absolute system, but it can certainly be improved and evolved.

\section{Research Methodology}

This paper is an exploratory research, based on investigative techniques. It is a fundamental and qualitative research that aims to present the most accurate current approach of double-entry accounting. I would like to promote an innovative method of learning and understanding the basic accounting principles: visual, 
tabular, and graphic. This paper begins with the authors' teaching experience, during several years of high school and university lecturing and researching. The current research is based mainly on the visual method of delivering the nature of accounts, since this teaching methodology leads to a much deeper and quicker understanding.

\section{Literature Review}

In order to deepen the development of accounting techniques, first of all it is necessary to provide a complete and analytical framework of the literature review concerning the nature of the accounts. Secondly, according to the international widespread classification of the nature of accounts it is possible to present the following distinction.

Real accounts are considered all assets of a firm, which can be classified as tangible or intangible, a balance sheet account that is carried forward into the next year. It is a proprietary account (Shim, J.K., Siegel, J.G., Dauber, N., Qureshi, A.A., 2014). Tangible real accounts are related to items that can be touched and felt physically (tools, buildings, machinery, inventory stock, land). Intangible real accounts are related to items that cannot be touched (goodwill, patents, trademarks, software licenses, brands, copyrights).

Debit: what comes in Credit: what goes out

Personal accounts are those related to both individuals and companies (debtors, creditors, banks, outstanding/prepaid accounts, accounts of credit customers, accounts of goods suppliers, capital, drawings). Private accounts are related to individuals (e.g. Mr. X's A/C, Mrs. Y's A/C). Corporate accounts are related to any type of business, private or public (companies, institutions). Representative personal accounts are related to a certain person or a group directly or indirectly (employees, wage-prepaid account).

\section{Debit: the receiver}

\section{Credit: the giver}

Nominal accounts are related to expenses, losses, incomes or gains. Existing by name only, they do not exist in physical form, but related to any nominal account, income statement account (revenue and expense) that is closed out at the end of the year (Shim, J.K., Siegel, J.G., Dauber, N., Qureshi, A.A., 2014).

Debit: expenses and losses

Credit: incomes and gains

The above-described international classification focuses on the material essence of the accounts, but has no direct connection with the accounting equation and it is referred to the original classification (Pacioli, L., 1494).

As a result of the growing importance of the accounting, academicians and experts in the twentieth century have largely deepened the study of nature of accounts to be able to create a simple, intuitive and rigorous system to post the accounts in the financial statement.

The theoretical framework designed by Gino Zappa (Dagnino, G.B., Quattrone, P., 2006; Fiume, R., 2007), father of the modern Italian business economics, has defined the earnings system. According to this classification, it is possible to distinguish (a) the original numerical accounts, represented by the exchanges of monies and its equivalents, and (b) the derived economic accounts, referred to economic measures, (Arduini, S., 2009; Manni, F., 2018; Manni, F., 1996), which are distinguished, in their turn, as economic accounts of capital, and earnings economic accounts.

Gino Zappa suggested the application of the inductive-deductive research method to business economics. He was indeed firmly convinced that there were no immutable laws, as scholars traditionally assumed. For this reason, the research had to start from the observation of reality, from which the subsequent deductions had to be drawn to solve specific problems (Billio, M., Coronella, S., Mio, C., Sostero, U., 2018). The earnings system has revolutionized the way of keeping the accounting records, until then set according to the patrimonial original Venetian logic. While applying the inductive-deductive research method, Gino Zappa understood first that the physiological evolution of companies required a radical change in the accounting logic that led to the detection of management operations. Therefore, in the nineteenth century, 
entrepreneurs and owners were mainly interested in the dynamics of assets and equity, which increased or decreased as a function of the positive or negative economic results.

The current widespread approach, invented by Aldo Amaduzzi, is called capital and earnings system, identifying the nature of the accounts as described by contemporaneous academics (Melis, A., 2007). It outlines the original (financial) and derivative (economic) accounts (Manni, F., 1996; Manni, F., 2008; Manni, F., Faccia A., 2015; Manni, F., Faccia, A., 2019).

Financial accounts include cash, operating receivables, operating payables, financial receivables and financial payables. Financial accounts underline the original aspect, concerning cash inflows and outflows, as well as increases and decreases of receivables and payables. In practice, there are three types of financial accounts: certain, assimilated, and assumptive. These are explained below.

Certain accounts include most current liquidity (cash, bank).

Debit: increase of cash

Credit: decrease of cash

Assimilated accounts include deferred values (receivables from customers, payables to suppliers, settlements receivables and payables), to sum up, operating receivables and payables.

\begin{tabular}{|c|r|}
\hline $\begin{array}{c}\text { Debit: increase of credit } \\
\text { (or) decrease of debit }\end{array}$ & Credit: decrease of credit \\
\hline
\end{tabular}

Assumptive accounts include accrued receivables, accrued payables, and funds.

\begin{tabular}{|c|r|}
\hline $\begin{array}{c}\text { Debit: increase of credit } \\
\text { (or) decrease of debit }\end{array}$ & $\begin{array}{r}\text { Credit: decrease of credit } \\
\text { (or) increase of debit }\end{array}$ \\
\hline
\end{tabular}

Economic accounts include multi-annual expenses (exhaust their usefulness in more than one period), operating costs and revenues (exhaust their usefulness in one period), and the equity. Economic accounts enhance the derivative aspect to identify the causes of each financial transaction, cost, revenue, and change in equity. In practice, there are four types of economic accounts: earnings of the period, earnings multiannual, earnings suspended, and capital. These are explained below.

Earnings of the period consist in costs and revenues fully accrued in the period.

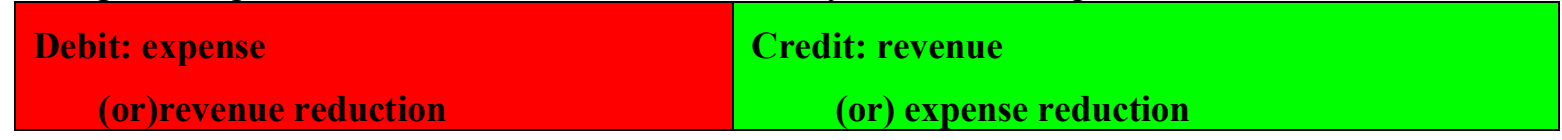

Earnings multi-annual are economic accounts which can be both credited and debited (two-side accounts) and refers to material and intangible assets.

\begin{tabular}{|l|l|}
\hline $\begin{array}{l}\text { Debit: durable expense increase } \\
\text { (due to purchase, } \\
\text { bartering or impairment) }\end{array}$ & $\begin{array}{l}\text { Credit: durable expense reduction } \\
\text { (due to disposal, impairment or depreciation) }\end{array}$ \\
\hline
\end{tabular}

Earnings suspended are referred to costs and revenues of deferred allocation (inventories and deferral, prepaid expenses and unearned revenues).

\begin{tabular}{|c|c|}
\hline $\begin{array}{c}\text { Debit: expense paid, } \\
\text { but still not accrued }\end{array}$ & $\begin{array}{c}\text { Credit: revenue collected, } \\
\text { but still not accrued }\end{array}$ \\
\hline
\end{tabular}

Capital accounts are related to equity risk capital and reserves.

\begin{tabular}{|l|l|}
\hline $\begin{array}{l}\text { Debit: capital refund } \\
\text { (withdrawal) }\end{array}$ & Credit: capital contribution \\
\hline
\end{tabular}




\section{Conclusions, Discussion and Recommendations}

The aim of this research paper is to review the evolution of accounting practices, analyzing the main evolutionary steps that occurred in different historical periods in accordance with social needs. The aim of this research is also to analyze the technical consequences and the advantages determined by the introduction of the evolutions themselves.

The author has highlighted that at least three periods (see Figure No. 1) in which substantial changes have occurred and can be identified: 1) the origin of scientific accounting, determined according to the written accounting reference (Pacioli, L., 1494); 2) implementation of accounting for enduring businesses, with the introduction of adjusting entries and the study of the nature of the accounts; and, 3) the possibility of practically implementing the triple-entry with the application of block chain technology.

DOUBLE-ENTRY

COMIMIERCIAL REVOLUTION

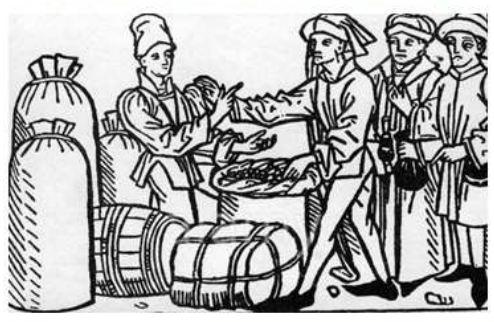

MIDDLE-AGES
ADJUSTING ENTRIES

INDUSTRRIAL, REVOLUTTION

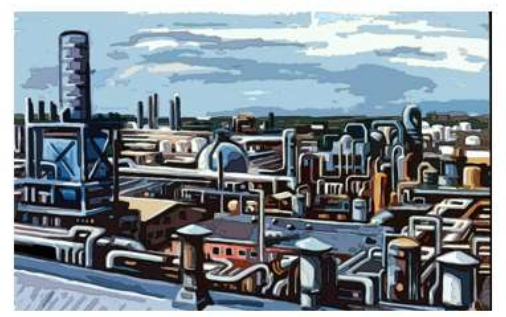

MODERN AGE
TRIPLE-ENTRY

DIGITAL REVOLLUTION

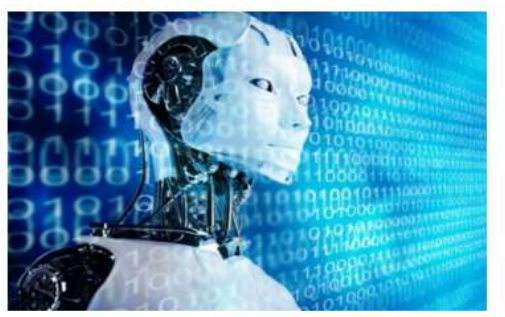

CONTEMPORARY AGE

Figure 1. The Accounting Revolutions

Source: completed by author.

\subsection{The Origin of Scientific Accounting: The Double-entry Bookkeeping System}

At the end of the fifteenth century, commercial exchanges in the Mediterranean were very intense, particularly among the Italian maritime republics and Arab traders in the Middle East. It is also likely that the double-entry bookkeeping system originated from the possible influence of the practice of Arab accounting, practiced and implemented by the Venetians (Pryor J.H., 1997). Even the name of the Journal, in Venice Zornal, has a very strong assonance with the equivalent book used in the Middle East Jaridah (Zaid, O.A., 2000). Nor can it be ruled out that religion (Spellman W.L., 2000) represented a driving force for innovation. At the beginning, both Muslim and Christian religions used to have the same visions related to money: money was just a medium of exchange, back in that time there was no notion of time value of money (Pryor J.H., 1997). Even, if to a different extent, the lending of money with interest was forbidden. However, the merchants' needed to find a source of finance which led to the invention of a new legal form of governance that made it possible to circumvent the prohibition (sharing profit instead of charging interests): and the partnership (Pryor J.H., 1997). Two types of partners were identified: a limited partner (limited liability partner), usually the capitalist who wanted to finance a project without risking all his assets, but who still wanted to get a return on his money; and, a general partner (unlimited partner), usually a merchant who wanted to make money and also risked his life by sailing and travelling.

The spread of these new ventures forced the merchants to provide detailed reports, through an advanced accounting practice, to determine the final profit to be shared with the capitalists. The partnership forms took on the name of Commenda in Italy and Mudarabah or Qirad in the Middle East, but the model of governance was substantially the same. 


\subsection{Accounting for Enduring Business: Adjusting Entries and the Nature of Accounts}

The aim of this research paper is to spread, through a scrupulous translation and a deep analysis and reelaboration, the method of classification of the nature of the accounts currently used in Europe (see Tables No. 1, 2, 3), raising the accounting culture around the world.

The knowledge of this classification is certainly useful, also and above all, to teach accounting in universities using a rigorous, complete, and consistent method (Faccia A. Mosteanu N.R. May 2019; Faccia A. Mosteanu N.R. April 2019).

The author, in this paper, also identifies a three-dimensional graphic according to three perspectives (Figure No. 2): horizontal axis -accounting equation / left side - Assets, right side - Equity \& Liabilities; vertical axis - above - economic accounts, below - financial accounts; concentric circles - external circle - long term; inner circle - short term.

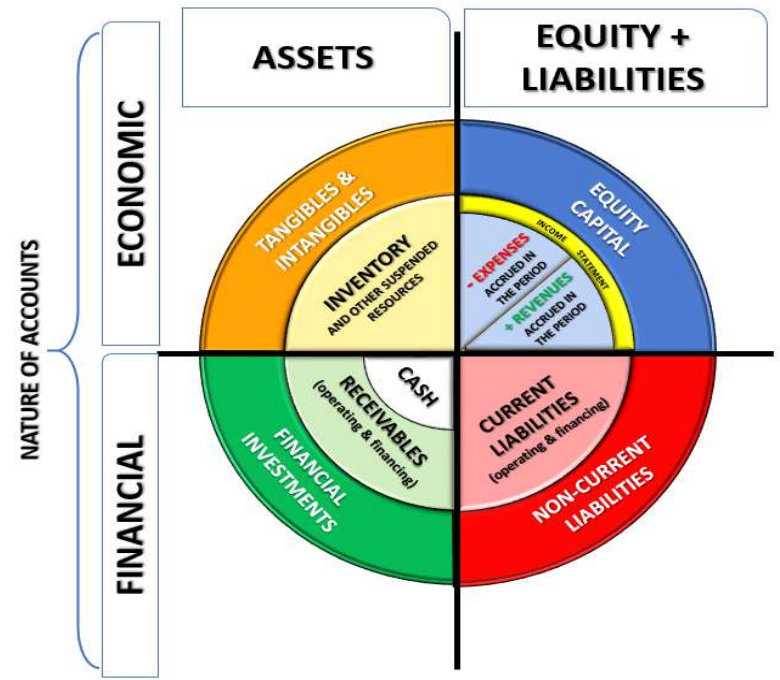

Figure No. 2 A Three-dimensional View of Accounts

Source: completed by author.

Table 1. Chart of Accounts, the nature of main accounts (examples)

\begin{tabular}{|l|c|c|}
\hline \multicolumn{1}{|c|}{ Name of Account } & $\begin{array}{c}\text { International } \\
\text { Approach }\end{array}$ & \multicolumn{1}{c|}{$\begin{array}{c}\text { Italian } \\
\text { Approach }\end{array}$} \\
\hline Raw material expense & Nominal & EEPE - Expense \\
\hline Rent expense & Nominal & EEPE - Expense \\
\hline Wages/Salaries expense & Nominal & EEPE - Expense \\
\hline Interest expense & Nominal & EEPE - Expense \\
\hline Maintenance expense & Nominal & EEPE - Expense \\
\hline Transportation expense & Nominal & EEPE - Expense \\
\hline Insurance expense & Nominal & EEPE - Expense \\
\hline Factoring charges & Nominal & EEPE - Expense \\
\hline Sales return & Nominal & EEPE - Expense \\
\hline Sales allowance & Nominal & EEPE - Expense \\
\hline Loss on disposal assets & Nominal & EEPE - Expense \\
\hline Utility bills expense & Nominal & EEPE - Expense \\
\hline Service expense & Nominal & EEPE. Expense \\
\hline Loss on bonds & Nominal & EEPE - Expense \\
\hline Discount on bonds & Nominal & EEPE - Expense \\
\hline Bad debt expense & Nominal & EEPE - Expense \\
\hline Write off receivable & Nominal & EEPE - Expense \\
\hline Income taxes expense & Nominal & EEPE - Expense \\
\hline Depreciation & Nominal & \\
\hline
\end{tabular}


Table 1 (cont.). Chart of Accounts, the nature of main accounts (examples)

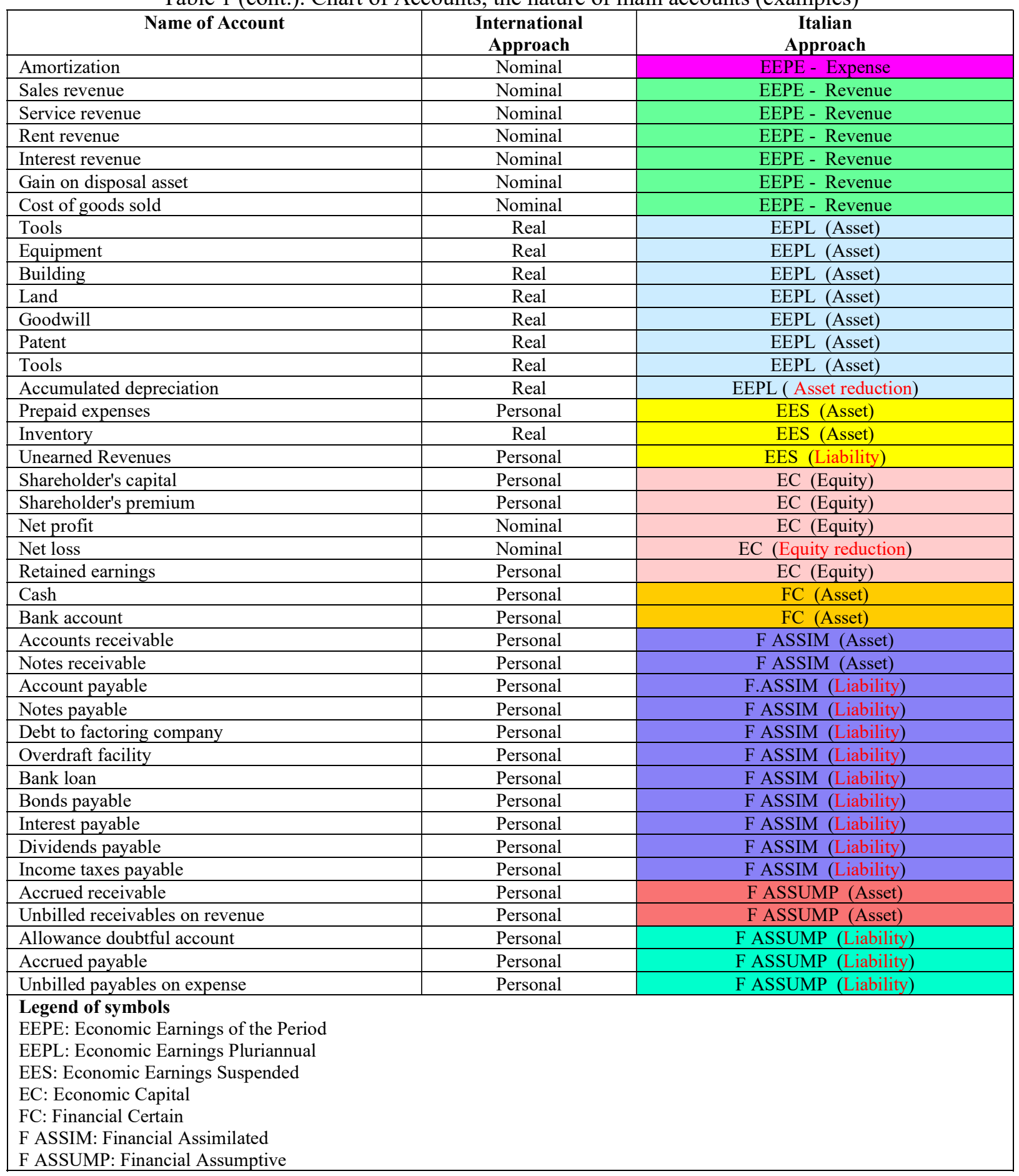

Source: completed by author. 
Table 2. Economic nature of main accounts (examples)

\begin{tabular}{|c|c|c|c|c|c|c|c|c|c|c|c|c|c|c|}
\hline \multirow{3}{*}{ NATURE } & \multicolumn{14}{|c|}{ ECONOMIC } \\
\hline & \multicolumn{12}{|c|}{ EARNINGS BASED } & \multirow{2}{*}{\multicolumn{2}{|c|}{ CAPITAL }} \\
\hline & \multicolumn{4}{|c|}{ ACCRUED IN THE PERIOD } & \multicolumn{4}{|c|}{ MULTI-ANNUAL } & \multicolumn{4}{|c|}{ SUSPENDED } & & \\
\hline \multirow{2}{*}{ DESTINATION } & \multicolumn{4}{|c|}{$\begin{array}{l}\text { INCOME STATEMENT } \\
\text { BALANCE SHEET }\end{array}$} & \multicolumn{4}{|c|}{ BALANCE SHEET } & \multicolumn{4}{|c|}{ BALANCE SHEET } & \multicolumn{2}{|c|}{ BALANCE SHEET } \\
\hline & \multicolumn{4}{|c|}{ EQUITY RETAINED EARNINGS } & \multicolumn{4}{|c|}{ ASSETS } & \multicolumn{2}{|c|}{ ASSETS } & \multicolumn{2}{|c|}{ LIABILTIES } & \multicolumn{2}{|c|}{ EQUTTY CAPTAL } \\
\hline $\begin{array}{l}\text { ACCORDANCE TO T- } \\
\text { ACCOUNTS }\end{array}$ & EXPENSE & $\begin{array}{l}\text { EXPENSE } \\
\text { REDUCTIION }\end{array}$ & $\begin{array}{l}\text { REVENUEE } \\
\text { REDECTION }\end{array}$ & REVENUE & $\begin{array}{l}\text { INCREASE } \\
\text { ASSETS }\end{array}$ & $\begin{array}{c}\text { DECREASE } \\
\text { ASSETS }\end{array}$ & $\begin{array}{l}\text { INCREASE } \\
\text { ASSETS }\end{array}$ & $\begin{array}{c}\text { DECREASE } \\
\text { ASSETS }\end{array}$ & $\begin{array}{c}\text { INCREASE } \\
\text { ASSETS }\end{array}$ & $\begin{array}{c}\text { DEEREASE } \\
\text { ASSETS }\end{array}$ & $\begin{array}{l}\text { DEEREASE } \\
\text { LABELITYY }\end{array}$ & $\begin{array}{l}\text { INCREASE } \\
\text { LABELITYY }\end{array}$ & $\begin{array}{l}\text { DECREASEE } \\
\text { EQUITYY }\end{array}$ & $\begin{array}{l}\text { INCPEASE } \\
\text { EQUITY }\end{array}$ \\
\hline $\begin{array}{l}\text { T-ACCOUNTS } \\
\text { SECTION }\end{array}$ & DEBIT & & & CREDTT & DEBIT & & & CREDTT & DEBIT & & & CREDTT & DEBIT & CREDTT \\
\hline \multirow{2}{*}{ MEANING } & $+\cos \mathrm{T}$ & & & + REVENUES & $+\cos \mathrm{T}$ & & & $-\cos T$ & $\begin{array}{l}\text { SUSPENDED } \\
\text { COST }\end{array}$ & & & $\begin{array}{l}\text { SUSPENDED } \\
\text { REVENIE }\end{array}$ & REFUND & CONTRBBUTION \\
\hline & - & & & + & - & & & + & - & & & + & \multirow{2}{*}{\multicolumn{2}{|c|}{ SHAREOLDER'S CAPTTAL }} \\
\hline \multirow{11}{*}{$\begin{array}{c}\text { LIST OF } \\
\text { T-ACCOUNTS }\end{array}$} & \multirow{2}{*}{\multicolumn{2}{|c|}{$\begin{array}{c}\text { RAW MATERIAL EXPENSE } \\
\text { RENT EXPENSE }\end{array}$}} & \multicolumn{2}{|c|}{ SALES REVENUE } & \multicolumn{2}{|c|}{ TOoLs } & \multirow{2}{*}{\multicolumn{2}{|c|}{ ACCUMULATED DEPRECIATION }} & \multirow{2}{*}{\multicolumn{2}{|c|}{$\begin{array}{l}\text { PREPAID EXPENSES } \\
\text { INVENTORY }\end{array}$}} & \multicolumn{2}{|c|}{ UNEARNED REVENUES } & & \\
\hline & & & SERVICE & VENUE & \multicolumn{2}{|c|}{ EQUIPMENT } & & & & & & & \multicolumn{2}{|c|}{ SHAREHOIDER'S PREMIUM } \\
\hline & \multirow{2}{*}{\multicolumn{2}{|c|}{$\begin{array}{l}\text { WAGES EXPENSE } \\
\text { INTEREST EXPENSEE }\end{array}$}} & \multicolumn{2}{|c|}{ RENT REVENUE } & \multirow{2}{*}{\multicolumn{2}{|c|}{ BUILDING }} & & & & & & & \multirow{2}{*}{\multicolumn{2}{|c|}{ + NET PROFIT }} \\
\hline & & & INTERES & EVENUE & & & & & & & & & & \\
\hline & MAINTEN & CE EXPENSE & GAINON DI & SAL ASSET & & & & & & & & & & Loss \\
\hline & TRANSPORT & ION EXPENSE & GAIN O & BOND & & & & & & & & & (RETAIN & EARNINGS) \\
\hline & INSURAI & EXPENSE & COST OF & OD SOLD & & & & & & & & & & \\
\hline & FACTOR & CHARGES & & & & & & & & & & & & \\
\hline & & ETURN & & & & & & & & & & & & \\
\hline & SALE A & OWANCE & & & & & & & & & & & & \\
\hline & INCOME T & ES EXPENSE & & & & & & & & & & & & \\
\hline
\end{tabular}

Source: completed by author.

Table 3. Financial nature of main accounts (examples)

\begin{tabular}{|c|c|c|c|c|c|c|c|c|c|}
\hline \multicolumn{2}{|c|}{ CERTAIN } & \multicolumn{4}{|c|}{ ASSIMILATED } & \multicolumn{4}{|c|}{ ASSUMPTIVE } \\
\hline \multicolumn{2}{|c|}{$\begin{array}{c}\text { CASH FLOW STATEMENT } \\
\text { BALANCE SHEET }\end{array}$} & \multicolumn{4}{|c|}{ BALANCE SHEET } & \multicolumn{4}{|c|}{ BALANCE SHEET } \\
\hline \multicolumn{2}{|c|}{ ASSETS } & \multicolumn{2}{|c|}{ ASSETS } & \multicolumn{2}{|c|}{ LIABILITIES } & \multicolumn{2}{|c|}{ ASSETS } & \multicolumn{2}{|c|}{ LIABILITIES } \\
\hline $\begin{array}{l}\text { INCREASE } \\
\text { ASSETS }\end{array}$ & $\begin{array}{l}\text { DECREASE } \\
\text { ASSETS }\end{array}$ & $\begin{array}{l}\text { INCREASE } \\
\text { ASSETS }\end{array}$ & $\begin{array}{l}\text { DECREASE } \\
\text { ASSETS }\end{array}$ & $\begin{array}{l}\text { DECREASE } \\
\text { LIABILITIES }\end{array}$ & $\begin{array}{l}\text { INCREASE } \\
\text { LIABILITIES }\end{array}$ & $\begin{array}{l}\text { INCREASE } \\
\text { ASSETS }\end{array}$ & $\begin{array}{l}\text { DECREASE } \\
\text { ASSETS }\end{array}$ & $\begin{array}{l}\text { DECREASE } \\
\text { LIABILITIES }\end{array}$ & $\begin{array}{l}\text { INCREASE } \\
\text { LIABILITIES }\end{array}$ \\
\hline DEBIT & CREDIT & DEBIT & CREDIT & DEBIT & CREDIT & DEBIT & CREDIT & DEBIT & CREDIT \\
\hline+ CASH & - CASH & + CREDIT & - CREDIT & - DEBIT & + DEBIT & + CREDIT & - CREDIT & - DEBIT & + DEBIT \\
\hline+ & - & + & - & + & - & + & - & + & - \\
\hline \multicolumn{2}{|c|}{ CASH } & \multicolumn{2}{|c|}{ ACCOUNT RECEIVABLE } & \multicolumn{2}{|c|}{ ACCOUNT PAYABLE } & \multicolumn{2}{|c|}{ ACCRUED RECEIVABLE } & \multirow{2}{*}{\multicolumn{2}{|c|}{$\begin{array}{l}\text { ALLOWANCE DOUBTFUL } \\
\text { ACCOUNT }\end{array}$}} \\
\hline \multicolumn{2}{|c|}{ BANK ACCOUNT } & \multicolumn{2}{|c|}{ NOTE RECEIVABLE } & \multicolumn{2}{|c|}{ NOTE PAYABLE } & \multirow{2}{*}{\multicolumn{2}{|c|}{$\begin{array}{l}\text { UNBILLED RECEIVABLES ON } \\
\text { REVENUE }\end{array}$}} & & \\
\hline & & & & DEBT TO FACT & ING COMPANY & & & \multirow{2}{*}{\multicolumn{2}{|c|}{$\begin{array}{l}\text { UNBILLED PAYABLES ON } \\
\text { EXPENSE }\end{array}$}} \\
\hline & & & & \multicolumn{2}{|c|}{ OVERDRAFT FACILITY } & & & & \\
\hline & & & & \multirow{2}{*}{\multicolumn{2}{|c|}{$\begin{array}{l}\text { BANK LOAN } \\
\text { BOND PAYABLE }\end{array}$}} & & & \multicolumn{2}{|c|}{ ACCRUED PAYABLE } \\
\hline & & & & & & & & \\
\hline & & & & \multicolumn{2}{|c|}{ INTEREST PAYABLE } & & & & \\
\hline & & & & \multicolumn{2}{|c|}{ DIVIDEND PAYABLE } & & & & \\
\hline & & & & \multirow{2}{*}{\multicolumn{2}{|c|}{ INCOME TAXES PAYABLE }} & & & & \\
\hline & & & & & & & & & \\
\hline
\end{tabular}

Source: completed by author.

The theoretical part is accompanied by Tables No. 1, 2, and 3 and the graphic (Figure No. 2) representation. The visual method leads this author to the conclusion that the students and the academics that studied the process of learning accounting, gain significant knowledge, compared to the accounting equation approach.

This paper underlines why we need to record some transactions in the debit section, and others in the credit section. Current practice shows that the accounting system itself, despite all the legislative rigors, still provides room for errors, expressed or forced, which, over time, lead to the development of the phenomenon of financial fraud. Therefore, this author suggests a new method to disseminate the knowledge and understanding of the exact nature of accounts, tabular and graphical, as a method to avoid errors too.

The author intends to implement the visual method in academic teaching, receiving feedback from students and academic colleagues from other universities, even using interviews based on questionnaires. 


\subsection{Accounting for the Contemporary Age: Triple Entry Bookkeeping System}

Nowadays, double-entry bookkeeping cannot be considered as an absolute system anymore. It is logically thanks to new technologies, the transition to triple entry is taking shape. Triple-entry bookkeeping includes a set of force in its third axis (Yuji, I., 1982). Blockchain, for the accounting industry, is starting to help the companies to record their transactions directly into a bookkeeping shared ledger, creating an interlocking system of enduring accounting records. Triple-entry accounting will add a level of transparency to bookkeeping that double-entry accounting cannot offer. The third public ledger allows for both parts of a transaction to reconcile their ledgers and make sure all three records are in a consensus (Unicorn, 2018). It shows that all transactions and all debits and credits involved can be seen. It is how, the salient feature of double-entry bookkeeping lies in the integration of flow accounts with stock accounts, its logical extension to triple-entry bookkeeping becomes clear, subsequently an integration of a new set of accounts designed to explain changes in flow accounts (Yuji, I., 1986).

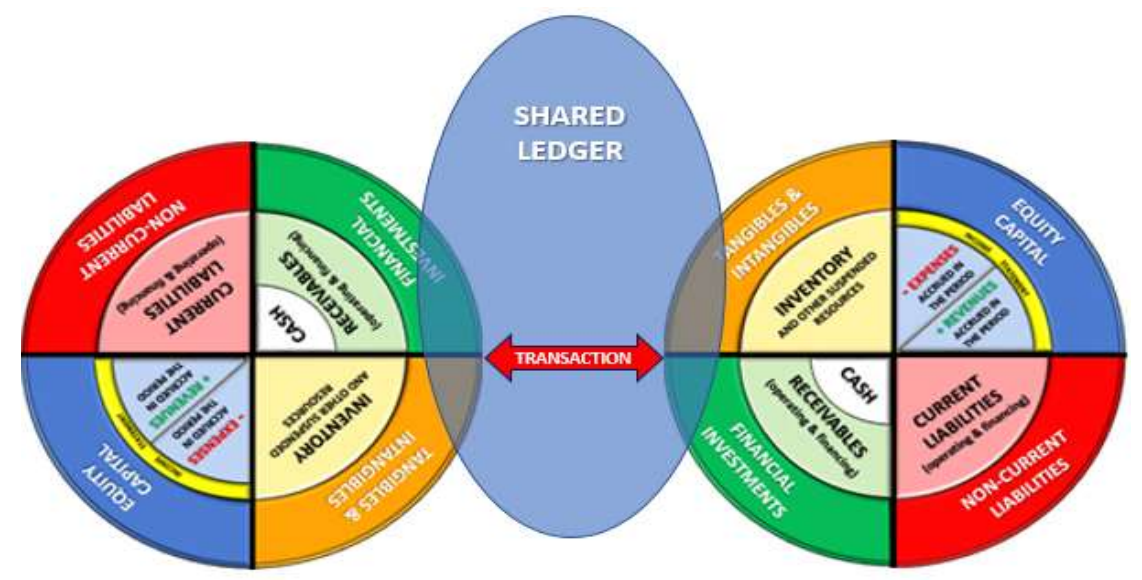

Figure 3. The Triple Entry Bookkeeping System

Source: completed by author.

The three-dimensional view of the accounts, described in paragraph 2 and shown in Figure No. 2, is useful again to represent the opposite relationship of a transaction between the two parties, also highlighting the shared ledger provided by the triple entry system (see Figure No. 3).

\subsection{Implication for the future}

Considering the imminent desirable integration of the third ledger for the bookkeeping system, future research, including the work that the Author is currently exploring, will have to focus on the study of the nature of the accounts in this added ledger. Moreover, it is assumed that the triple entry, which must integrate the double entry system, could always work with a balancing system, but still no author has defined the technical methods for balancing the third ledger. This paper, clarifying the nature of the accounts for the double entry bookkeeping system, in the perspective of integration, constitutes the basis for future research to find a logical basis for the entries to be recorded in the third ledger.

\section{References}

1. Arduini, S. (2009). Appunti di ragioneria generale, CEDAM.

2. Dagnino, G.B., Quattrone, P. (2006). Comparing institutionalisms: Gino Zappa and John R. Commons' accounts of "institution" as a groundwork for a constructivist view. Journal of Management History, $12(1), 36-52$.

3. Billio, M., Coronella, S., Mio, C., Sostero, U. (2018). Le discipline economico aziendali nei 150 anni di storia di Ca' Foscari - Gino Zappa il fondatore della economia aziendale, I libri di Ca' Foscari. (The 
business disciplines in the $\mathrm{Ca}$ - Foscari 150 years of history - Gino Zappa the founder of business economics, Ca 'Foscari books, 6.

4. Faccia A., Mosteanu N.R. (May 2019). Tax evasion, information system and blockchain, Journal of Information Systems \& Operations Management, Bucharest, 13, (1).

5. Faccia A., Mosteanu N.R. (April 2019). Accounting and blockchain technology: from double entry to triple entry, The business and Management Review, 10(2).

1. Fiume, R. (2007). Lorenzo de Minico's thought in the development of accounting theory in Italy: An understated contribution, Accounting, Business and Financial History, 17 (1), 33-52.

2. Houghton Budd, C. (2016). In the shoes of Luca Pacioli - double entry bookkeeping and financial literacy, International Handbook of Financial Literacy, 621-637.

3. Libby, R. (2017). Financial Accounting. McGraw-Hill Higher Education.

4. Needles, B.E., Powers, M. (2012). Financial Accounting. Cengage Learning.

5. Manni, F. (1996). Lineamenti di ragioneria generale. Il processo logico-contabile di formazione del bilancio ordinario d'esercizio. (Outlines of general accounting. The logical-accounting process of formation of the ordinary financial statements). Giappichelli Editore.

6. Manni, F. (2018). Il percorso logico contabile di costruzione del bilancio ordinario di esercizio.( The logical accounting path for the construction of the ordinary financial statements). Giappichelli Editore.

7. Manni, F., Faccia, A. (2015). Introduction to accounting. Aracne Editrice.

8. Manni, F., Faccia, A. (2019). Financial Accounting - Text and cases. Aracne Editrice.

9. Melis, A. (2007). Financial statements and positive accounting theory: The early contribution of Aldo Amaduzzi. Accounting, Business and Financial History, 17 (1), 53-62.

10. O’Bryan, D., Berry, K.T., Troutman, C., Quirin, J.J. (2000). Using the accounting equation analysis to teach the statement of cash flows in the first financial accounting course. Journal of accounting education, 18(2), 147-155.

11. Pacioli, L. (1494). Summa de arithmetica, geometria. Proportioni et proportionalita.

12. Pryor J.H. (1997). The origins of commenda contract. Speculum, 52(1), The University of Chicago Press.

13. Simoyama, F.D.O., Grigg, I., Bueno, R. L. P., and Oliveira, L.C.D. (2017). Triple entry ledgers with blockchain for auditing. International Journal of Auditing Technology, 3(3), 163-183.

14. Shim, J.K., Siegel, J.G., Dauber, N., Qureshi, A.A. (2014). Dictionary of accounting terms. 6th edition. Barron's business Guides.

15. Spellman W.L. (2000). The influence of Religion on the Globalization of Accounting Standards. Trinity Christian College.

16. Spiceland, D. (2016). Financial Accounting. McGraw-Hill Higher Education.

17. Sullivan, M.C., Benke Jr., R.L. (1997). Comparing introductory financial accounting textbooks. Journal of accounting education, 15(2), 181-220.

18. Warren, C., Reeve, J.M., Duchac, J. (2018). Financial Accounting. McGraw-Hill Higher Education.

19. Weygandt, J.J., Kieso, D.E., Kimmel, P.D. (2017). Financial Accounting. Wiley.

20. Wild, J. (2017). Fundamental Accounting Principles. McGraw-Hill Higher Education.

21. Williams, J. (2018). Financial Accounting. McGraw-Hill Higher Education.

22. Yuji, I. (1982). Triple-Entry Bookkeeping and Income Momentum, American Accounting Association.

23. Yuji I. (1986). A framework for triple-entry bookkeeping. The Accounting Review, 61(4).

24. Zaid, O.A. (2000). Were islamic records precursors to accounting books based on the Italian Method? Accounting Historians Journal. 